\title{
MUSIK JAZZ MELAYU DALAM KAJIAN KREATIVITAS
}

\author{
Tri Warta Hadi Sahputra, Martarosa, dan Zainal Warhat \\ Minat Studi Pengkajian Seni Musik Barat Program Pascasarjana \\ Institut Seni Indonesia Padangpanjang, Indonesia \\ Email: Triwartahadisahputra@yahoo.com \\ No. Hp: 082386833219
}

\begin{abstract}
Malay music is the genre of traditional music that starts and evolves in the area of Sumatera east coast, Kalimantan, and Semenanjung Malaya. This music is usually sung by people from Malay tribe and sometimes accompanied by local Malay dances in tribute events such as welcoming honorable guests in customary event and religious events. Malay music has undergone the change of music style in accordance with the development of era such as the fusion with pop, jazz, and dangdut. The existence and consistency of Malay music are embodied through the process of creativity in the effort of globally developing Malay music. It means that it's not only upholding the value of its originality but also following the direction of era development. Hybridity becomes one of strengths of Malay music and differentiates this music genre from other genres. Malay music accepts all differences; Malay music even fuses all existing elements. Method used in interpreting the existing phenomena were seeing the process happened, ethnography, art research method, and historical reading.
\end{abstract}

Keywords: Creativity, Existence, Consistency

\begin{abstract}
ABSTRAK
Musik Melayu adalah aliran musik tradisi yang bermula dan berkembang di wilayah pantai timur Sumatra, Kalimantan, dan Semenanjung Malaya. Musik ini biasanya dinyanyikan oleh orang-orang dari suku bangsa Melayu yang tidak jarang diiringi pula dengan tarian khas Melayu setempat dalam acara-acara persembahan seperti: penyambutan tetamu kehormatan dalam perhelatan atau pesta adatdan kegiatan serimonial keagamaan. Seiring dengan perkembangan zaman musik melayu mengalami perubahan gaya music seperti, perpaduan dengan aliranmusik pop, jazz, dan dangdut. Eksistensi dan konsistensi musik melayu diwujudkan melalui proses kreativitasdalam upaya pengembangan musikmelayu secara global. Dalam arti tidak semata-mata bersikeras menjunjung nilai keasliannya saja, tetapi musik melayujuga mengikutiarah perkembangan zaman. Hibriditas menjadisalah satu kekuataan musik melayu, dan membedakan jenis musik ini dengan yang lain. Musik melayu menerima segala perbedaan, bahkan musik melayu memadupadankan seluruh elemen yang ada. Dalam melihat proses yang terjadi, etnografi, metode penelitian seni dan pembacaan sejarah menjadi metode yang digunakan dalam menafsirkan fenomena yang ada.
\end{abstract}

Kata Kunci: Kreativitas, Eksistensi, Konsistensi, 


\section{PENDAHULUAN}

Pekanbaru merupakan ibu Kota Propinsi Riau yang memiliki perkembangan yang sangat cepat baik secara putaran ekonomi masyarakat maupun dalam perkembangan kesenian dan kebudayaan seperti musik-musik tradisional melayu yang sering dipertunjukkan di Kota Pekanbaru Riau. Musik merupakan salah satu wujud dari kesenian yang dapat digunakan untuk melengkapi kebutuhan manusia secara nilai estetikanya, menurut Linton, musik diartikan sebagai pengorganisasian bentuk dari suara, baik berupa kebisingan atau (noise) atau nada-nada yang harmonis selain fungsi pemenuhan kebutuhan akan nilai estetika, musik juga banyak memiliki kegunaan lain bagi setiap insan yang menikmatinya entah sebagai seorang pemain musik, maupun sebagai pendengar. Musik juga menjadi sebuah bahasa yang dapat berlaku secara universal, tanpa mengenal pembagianpembagian seperti halnya: batas wilayah, usia, kelas, gender maupun strata sosial (dalam Arved 2004:5).

Dalam membuat suatu karya musik orang akan mengetahui pesan yang didapat dalam musik tersebut baik secara emosional maupun secara intuisional dengan tanpa banyak bicara hanya dengan mendengarkan nada-nada orang akan bisa merasakan emosional serta pesan apa yang mau disampaikan melalui musik yang dibawakan.

Dalam konteks kebudayaan di seluruh dunia, seni musik yang hidup dan berkembang di dalam masyarakat tertentu, menjadi identitas kebudayaan mereka secara umum, musik memegang peranan penting dalam konteks kontinuitas dan perubahan kebudayaan, musik mengandung aspek-aspek struktural, estetika, fungsional, kontekstual, yang biasa juga berhubung erat dengan berbagai cabang seni lain seperti tari, sastra, teater, rupa, bahkan media, musik menjadi bahagian dari kehidupan seharihari, atau juga adat-istiadat, ritual, rahasia kelompok, dan lain-lainnya (Hamzah, 1988:76). Pada prinsipnya, musik terdiri dari wujud gagasan, seperti konsep tentang ruang: tangganada, wilayah nada, nada dasar, interval, frekuensi nada, sebaran nada-nada, kontur, formulamelodi, dan lain-lainnya. Dimensi ruang dalam musik ini merupakan organisasi suara, sementara, di sisi lain, musik juga dibangun oleh dimensi waktu, yang terdiri dari: metrum ataubirama, nilai not (panjang pendeknya durasi not), kecepatan (seperti lambat, sedang, cepat,sangat cepat), dan lainnya.

Dalam konteks budaya Melayu sendiri, integrasi antara musik dengan kesenian lainnya terwujud dalam konsep garapannya. Dengan demikian, budaya musik menjadi bagian yang tak terpisahkan dengan kebudayaan melayu pada umumnya. Secara fungsional, pertunjukan musik tradisional mengikuti aturan-aturan tradisional. Pertunjukan ini, selalu berkaitan dengan penguasa alam, mantera (jampi) yang tujuan mengkomunikasikan suatu kepercayaan 
untuk menjauhkan bencana, mengusir hantu, atau setan. Musik tradisi Melayu berkembang secara improvisasi, berdasarkan transmisi tradisi lisan. Setiap musik mempunyai nama tertentu dan alat-alat musik mempunyai legenda asalusulnya. Pertunjukan musik mengikuti aturan dan menjaga etika permainan. Di lain sisi, terdapat pula berbagai jenis musik selain yang sifatnya tradisi di dalam budaya Melayu, seperti musik populer Melayu, musik akulturatif modern seperti musik jazz dan lain-lainnya.

Sebagai media untuk berkomunikasi musik jazz adalah merupakan salah satu bentuk aliran musik yang menjadi ciri khas musik Amerika. Musik jazz ini kemudian mulai deikenal hampir keseluruh dunia, akar dari musik jazz ini sendiri adalah akar dari musik blues, musik blues menghasilkan musik yang nantinya bernama ragtime, dan ragtime inilah yang akhirnya menjadi sebuah akar dari musik jazz, banyak yang menginterpretasikan asal musik jazz ini berasal dari musik-musik mars tentara Amerika. Yang lalu, di improvisasi sedemikian rupa, yang akhirnya menjadi musik jazz. Joachim Berendt mendefenisikan jazz sebagai sebuah bentuk seni musik yang berasal dari Amerika Serikat. Musik itu dimainkan orang-orang Afro-Amerika yang telah mengkontradiksikan musik-musik eropa ( Brendt, 1981:317). Berdasarkan uraian diatas musik yang berkembang pada saat ini di Kota Pekanbaru Riau salah satunya adalah musik yang bergenre jazz, dengan garapan-garapan yang berbentuk suatu sajian kreativitas dalam mengolah kembali musik-musik tradisi melayu Pekanbaru kebentuk musik tradisi modern yaitu musik tradisi melayu yang bercitarasa jazz melayu, salah satu yang mempopularitaskan musik jazz melayu kepada masyarakat penikmat seni di Kota Pekanbaru adalah grup yang bernama Geliga.Masyarakat melayu merupakan masyarakat yang sangat terbuka dengan masuknya unsur - unsur kebudayaan yang datang dari luar, kebudayaan yang datang dari luar ini kemudian diadopsi dengan sesuai dengan kebutuhan peradaban masyarakat Melayu itu sendiri. Kemudian kebudayaan tersebut di kelola dengan baik secara kreatif dan inovatif oleh masyarakat melayu, salah satunya adalah kesenian musik yang ada di ranah melayu itu sendiri.

Musik Melayu adalah aliran musik tradisional yang bermula dan berkembang di wilayah pantai timur Sumatera, Kalimantan, dan Semenanjung Malaya, musik ini biasanya dinyanyikan oleh orang-orang dari suku bangsa Melayu yang tidak jarang diiringi pula dengan tarian khas melayu setempat, misalnya tari Persembahan dalam perhelatan atau pesta adat, penyambutan tetamu kehormatan, dan dalam kegiatan keagamaan. Yang menarik dari aliran musik ini terletak pada susunannya yang terdiri dari lirik lagu yang mengandung syair yang disesuaikan dengan kehidupan sehari-hari dan penuh dengan tunjuk ajar pesan moral, diisi dengan suara atau 
vokal khas cengkok Melayu, dan aransemen musik yang tersusun rapi. Pada awal perkembangannya musik yang digunakan lebih didominasi oleh tingkahan rebana, petikan gambus, gesekan biola,picitan akordion, tangkahan gong, dan tiupan serunai. Ini dipengaruhi oleh kebudayaan dari tanah Arab dan Eropa tradisional. Seiring dengan perkembangan teknologi itu semua digantikan dengan alat musik elektronik berupa keyboard, walaupun demikian, dalam kegiatan-kegiatan tertentu alat musik tradisional masih tetap digunakan demi melestarikan warisan kebudayaan. Hal tersebut dikarenakan seni merupakan simbol dari perasaan yang ada pada diri manusia yang membudaya dalam kehidupan masyarakat melayu. Melihat seni dapat diibaratkan seperti orang yang sedang berkomunikasi baik secara audio, visual, maupun audio visual. Salah satu komunikasi yang dapat dilakukan dalam seni adalah seni musik, dalam Kamus Besar Bahasa Indonesia Musik adalah: ilmu atau seni menyusun nada atau suara diutarakan, kombinasi dan hubungan temporal untuk menghasilkan komposisi (suara) yang mempunyai keseimbangan dan kesatuan, nada atau suara yang disusun sedemikian rupa sehingga mengandung irama, lagu dan keharmonisan (terutama yang dapat menghasilkan bunyi-bunyi itu). Musik juga merupakan salah satu media ungkapan kesenian, musik mencerminkan kebudayaan masyarakat pendukung- nya. Di dalam musik terkandung nilai dan norma-norma yang menjadi bagian dari proses alkuturasi budaya, baik dalam bentuk formal maupun informal. Musik itu sendiri memiliki bentuk yang khas, baik dari sudut struktual maupun jenisnya dalam kebudayaan. Demikian juga yang terjadi pada musik dalam kebudayaan masyarakat melayu (Abdul Latif Abu Bakar, 2000:126).

Musik bagi masyarakat melayu bukanlah hanya sekedar kreasi artistik, tidak juga sekedar hiburan atau bersantai tetapi musik itu bersatu dengan berbagai aspek kebudayaan. Mulanya musik melayu hanya terdiri dari alat musicritmik (tepukan tangan atau rebana) dan vokal saja. Seiring perkembanga zaman musik melayu pun berkembang. Perkembangan tersebut dapat dilihat dari instrument dan aransemen nya. Hal itupun menjadikan beberaapa musisi Riau untuk mengembangkan kesenian melayu khususnya musik melayu, salah satunya adalah Geliga sebagai grup musik etnik melayu riau.Geliga berdiri di Riau pada tahun 2001 berhasil mengawinkan musik melayu dan musik jazz menjadi musik yang lebih barfariasi, sehingga menumbuhkan minat masyarakat terhadap musik melayu, karena pada masa sebelum era reformasi musik melayu kurang diminati oleh masyarakat melayu riau, sehingga terhambatnya perkembangan musik melayu tersebut (Eri Bob, wawancara di Pekanbaru 15 november 2015). 


\section{STUDI LITERATUR}

Pesatnya perkembangan era globalisasi dan teknologi musik, dapat mempengaruhi minat masyarakat terhadap musik daerah kota Pekanbaru, sehubung hal tersebut musik daerah di garap dalam bentuk inovasi maupun kreativitas, sehingga menghasilkan warna baru terhadap musik daerah kota Pekanbaru. Kreativitas diartikan secara berbeda-beda oleh para ahli. James Gallagher misalnya mengatakan bahwa, creativity is a mental process by which individuals create new ideas and products or recombine existing ideas and product (James Gallagher, Samuel Kirk, Mary Ruth,2014:457), Gallagher mengartikan kreativitas sebagai proses mental pada setiap individu. Melalui proses mental tersebut, manusia kemudian mampu melahirkan ide baru serta produk baru. Dan melalui adanya proses mental itu pula manusia dapat mengkombinasikan antara ide dengan produk yang sudah ada sebelumnya sehingga menjadi satu model produk yang benar-benar baru. Unsur kebaruan di sini menjadi titik tekan Gallagher dalam mengartikan kreativitas.

Garapan-garapan kreativitas yang diwujudkan dalam garapan musik melayu di kota Pekanbaru Riau memiliki suatu keinginan untuk mempresentasikan budaya melaui karya-krya inovasi dari Geliga. Group Geliga didirikan di Pekanbaru pada tahun 2001, yang didukung oleh sejumlah musisi dengan latar belakang dan pengalaman yang berbeda, kelompok grup musik tradisi ini mencoba berangkat dari keinginan untuk mengangkat khasanah musik melayu dengan memasukkan unsur-unsur musik jazz dan menjadi salah satu pilihan dari kelompok ini, Geliga memiliki arti batu mustika yang memancarkan sinar dan kecermelangan, dia menjadi idaman melayu sekaligus idaman kolektif, siapa yang menyimpan mustika itu dia bisa mengobati segala penyakit dan menghilangkan dahaga serta menghindari segala wabah dan bencana, dalam ungkapan melayu (otak ini bergeliga) artinya pemikiran yang amat cemerlang dan merengkuhzaman. Grup Geliga berhasil mengawinkan dua genre musik yaitu musik melayu dan musik jazz sehingga menghasilkan komposisi musik yang ciamik dan sangat recomended untuk di nikmati (https://geliga-instrumental-jazz-melayu-riau/).

Konsep garapan musik geliga ini adalah bertolak dari musik melayu yang biasa dikenal dengan rentak melayu seperti (zapin, gazal, joget, senandung, dan lainnya) dalam garapannya group geliga mencoba memadukannya dengan musik modern dengan style jazz, sehingga memberikan warna baru dalam nuansa musikal daerah melayu khususnya kota Pekanbaru sebagai musik popular.Raymond William dalam Story (2004), "populer" istilah populer ini memiliki empat makna: "banyak disukai orang", dan "budaya yang memang dibuat oleh orang untuk dirinya sendiri" (Adi: 2011:10). Menurut sebagian orang, populer memiliki arti secara umum 
digunakan untuk mengacu pada produkproduk yang diproduksi secara komersial, sementara arti yang lainnya mengacu pada bentuk-bentuk produk budaya "yang bersifat kerakyatan" (Shucker, 2001: 6). Oleh karenanya musik populer dalam globalisasi lebih cepat diterima oleh masyarakat urban atau perkotaan di Indonesia. Beragamnya suku, daerah dan etnis pada masyarakat perkotaan menjadikanpluralism kebudayaan lebih mudah melebur dan diterima oleh masyarakat heterogen dalam konteks musikal.

\section{METODE PENELITIAN}

Metode penelitian ini dilakukan dengan menelaah objek penelitian melalui metodologi penelitian kualitatif. Metode kualitatif adalah suatu proses penelitian dan pemahaman yang didasarkan pada metode untuk menyelidiki suatu fenomena sosial dan masalah manusia. Pada pendekatan ini, peneliti membuat suatu gambaran kompleks tentang kesenian musikjazz melayu, laporan terperinci dari pandangan responden, dan melakukan studi pada situasi yang lain (Creswell, J.W, 1998: 15). Sugiono mengatakan, metode penelitian kualitatif sering disebut metode penelitian naturalistik. Oleh karena penelitian ini dilakukan pada kondisi yang alamiah (natural setting), dan dapat juga disebut metode etnografi, karena awalnya metode ini lebih banyak digunakan dalam bidang antropologi budaya. Metode ini didukung oleh Moh.
Nazir yang mengatakan bahwa: Tujuan dari penelitian kualitatif adalah untuk membuat deskripsi, gambaran atau lukisan secara sistematis, faktual dan akurat mengenai fakta-fakta, sifat-sifat serta hubungan antar fenomena yang diselidiki. Metode kualitatif deskriptif, suatu objek, suatu set kondisi, suatu sistem pemikiran, ataupun suatu kelas peristiwa pada masa sekarang (Moh. Nazir, 1983: 63). Bogdan dan Taylor mengemukakan bahwa metodologi kualitatif merupakan prosedur penelitian yang menghasilkan data deskriptif berupa kata-kata tertulis maupun lisan dari perilaku dan orang-orang yang diamati (Lexy Moleong, 1988: 3). Oleh sebab itu, tujuan penelitian musik daerah Pekanbaru guna menjelaskan terwujudnya fakta musik modern yang mempengaruhi sehingga terbentuknya bentuk musik garapan baru yaitu jazz melayu, secara kajian kreativitas serta didukung dengan penjelasan secara musikologi dan estetika, yang berhubungan dengan peristiwa musik daerah Pekanbaru masa sekarang. Menurut Bodgan dan Taylor, penelitian kualitatif sebagai prosedur penelitian yang menghasilkan data deskriptif berupa kata tertulis atau lisan dari orang-orang dan perilaku yang dapat diamati (Bodgan, 1995: 3).

Melalui metode kualitatif di atas, maka penelitian ini dapat diarahkan pada penggunaan prosedur-prosedur dalam penelitian ini. Ketertarikan tersebut digunakan untuk menelusuri apresiasi masyarakat, dan seniman maupun 
masyarakat penikmat seni terhadap fenomena musik jazz melayu dan faktorfaktor eksternal yang mempengaruhi keberadaan Musik jazz melayu. Langkahlangkah yang digunakan melalui metode kualitatif adalah observasi, wawancara, dan dokumentasi.

\section{PEMBAHASAN}

\subsection{Musik Melayu}

Sebelum datangnya pengaruh seni pertunjukan Hindu, Islam, dan Barat, sebenarnya etnik Melayu telah memiliki konsep-konsep tersendiri tentang tangga nada atau ritme. Berdasarkan bentuk konsep musik melayu yang ada pada dulunya, baik yang diteruskan dari tradisinya, yang disebut bunyi-bunyian atau yang diambil dari Barat. Sebelum datangnya agama Hindu dan Islam ini, dapat dilihat dari kajian sistem music Melayu yang menggunakan suara dengan sebutan seperti mersik, garau, garau alang, dan pekak. Sebuah ide yang mencakup pengertian nada dengan karakteristik tertentu. Termasuk unsur pelarasan alat musik, yang dalam hal ini biasanya dihubungkan dengan biola dan rebab, sertasistem modus. Para pemusik dan pencipta lagu Melayu masa dahulu kala juga telah mengenalkonsep-konsep improvisasi, baik melodi atau ritme. Dalam improvisasi dikenal istilah-istilah: (1) cengkok yang berarti suatu ide improvisasi dengan teknik mengayunkan nada-nada, yang dalam musik Barat seperti teknik sliding pitch, dengan contoh seperti berikut:
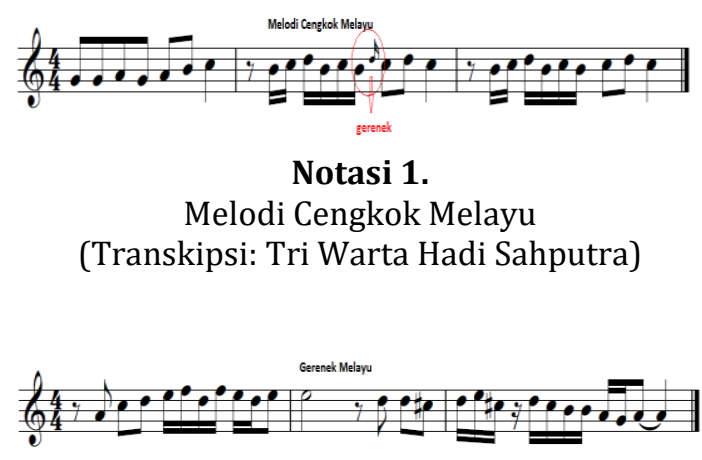

Notasi 2.

Melodi Gerenek Melayu (Transkipsi: Tri Warta Hadi Sahputra)

Konsep tentang ritme, seacra umum disebut rentak, yang mengandung pengertian pola-pola ritme, durasi, onomatopeik/tiruan bunyi oleh suara manusia pada berbagai tipe gendang, ostnato, dan lainnya, yang juga dapat dikaitkan dengan konsep-konsep hitungan, atau gerak yang diiringi rentak ini. Umumnya struktur tari mempunyai kesinkronan dengan konsep-konsep rentak musik. Di Pesisir Timur Sumatera Utara, pada umumnya hitungan pertama ritme bukan pada jatuhnya pukulan gong/tetawak, tetapi gong/tetawak dianggap sebagai akhir dari rangkaian siklus musik dan tarinya. Menurut Nasuruddin (1977:162).

\subsection{Musik Jazz}

Musik jazz adalah musik yang mencakup beberapa faktor yaitu: swinging. Swing ini menjadi ciri khas dari jazz itu sendiri, lalu faktor lainnya adalah improvisasi kemudian adanya interaksi diantara individu dalam sebuah grup. Lalu faktor berikutnya adalah mengem- 
bangkan ciri khas masing-masing musisi dari segi suara yang dihasilkan dari instrumentHingga menciptakan karekter sendiri dalam memainkan jazz itu lewat instrument-nya dan yang terakhir adalah musik jazz itu selalu terbuka pada kemungkinan-kemungkinan yang ada (Sutro,2006:31). Beberapa contoh scale dari musik jazz yang biasa digunakan dalam membuat suatu komposisi musik jazz sebagai berikut:

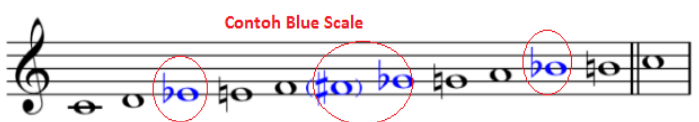

Notasi 3.

Blue Scale

(Transkipsi: Tri Warta Hadi Sahputra)

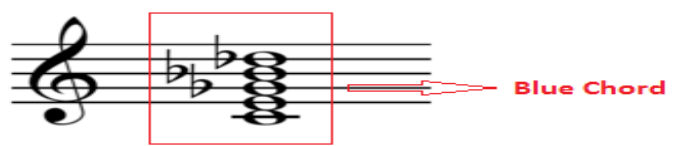

\section{PERSPEKTIF KAJIAN KREATIVI- TAS MUSIK JAZZ MELAYU}

Kreativitas adalah kebaruan dan kesesuain, Perkins mendefinisikan kreatifitas terbagi dari dua yaitu,(a) hasil kreatif adalah hasil asli dan persetujuan harga diri, (b) orang dengan kreativitas adalah orang yang cukup secara rutin menghasilkan hasil yang kreatif (Perkins. 1988:311). Kata "kreatif" digunakan pada akhir abad ke-19 yang digunakan untuk sebagai referensi seni dan puisi (Alane Jordan starco, 2005:31). Berdasarkan pendapat Perkins tersebut terwujudnya suatu karya dari kreativitas seseorang itu dipengaruhi dua hal yaitu: 1. Hasil Kreatifitas; 2. Orang dengan Krea-tifitas.
Notasi 4.

Blue chord

(Transkipsi: Tri Warta Hadi Sahputra)
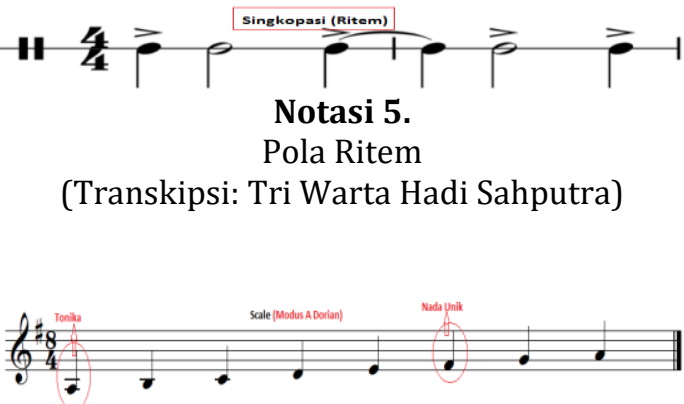

Notasi 6.

Scale (Modus)

(Transkipsi: Tri Warta Hadi Sahputra)

Berdasarkan penjelasan konsep dari bentuk melodi maupun harmoni yang ada pada musik melayu maupun musik jazz sangat memiliki suatu konsep bentuk yang berbeda dari segi melodi, harmoni maupun dari cara memainkannya.

Dalam dua konsep tersebut penelitian ini akan mencoba untuk membedah bagaimana terwujudnya karya-karya jazz melayu yang digarap oleh grup Geliga tersebut sehingga menimbulkan suatu warna baru dalam kesenian musik melayu di Kota Pekanbaru Riau. Untuk lebih jelasnya lihat contoh berikut: 


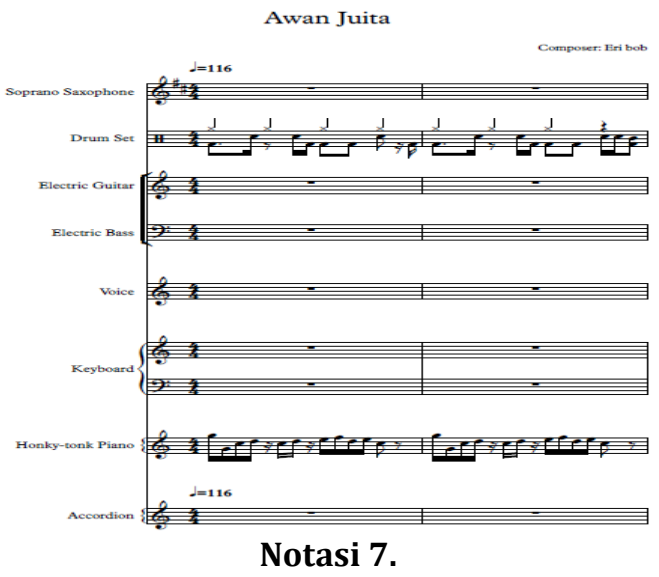

Repertoar Hasil Kreativitas

(Transkipsi: Tri Warta Hadi Sahputra)

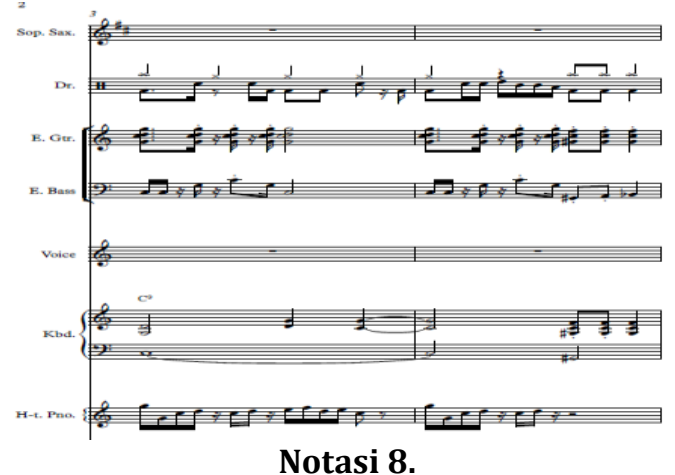

RepertoarHasil Kreativitas

(Transkipsi: Tri Warta Hadi Sahputra)
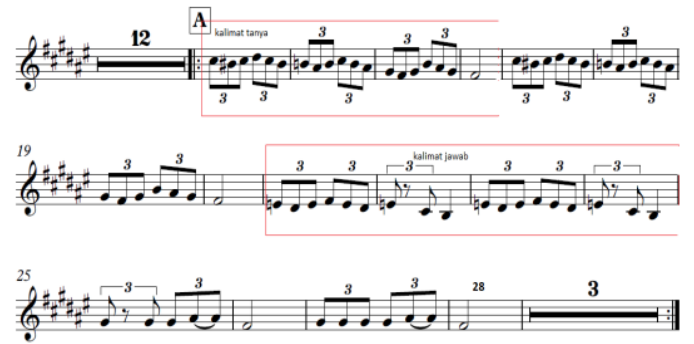

Berdasarkan latar penjelasan diatas dan fokus perspektif yang telah dijelaskan di atas, bisa disimpulkan bahwa antara musik tradisi melayu dan musik jazz itu memiliki bentuk yang berbeda, tetapi dengan adanya perwujudan dari kreativitas grup geliga untuk menciptakan suatu karya inovasi

\section{Notasi 9.}

Cengkok Melayu Hasil Kreativitas

(Transkipsi: Tri Warta Hadi Sahputra)

Karya ini adalah hasil dari kreativitas dari grup Geliga untuk menjadikan musik tradisi melayu di Pekanbaru kembali menjadi konsumsi publik secara umum bukan untuk masyarakat penikmat seni saja.

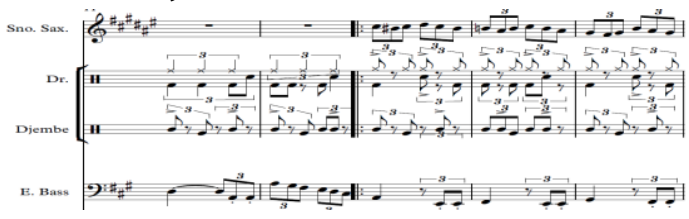

Notasi 10.

Pola Ritem Orang dengan Kreativitasnya

(Transkipsi: Tri Warta Hadi Sahputra)

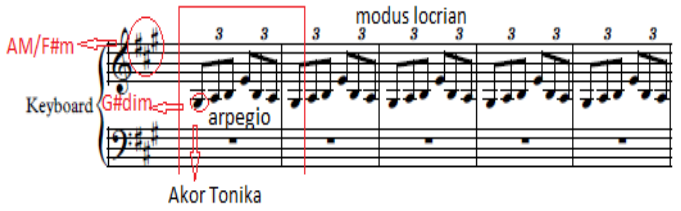

Notasi 11.

Modus Locrian Orang dengan Kreativitasnya

(Transkipsi: Tri Warta Hadi Sahputra)

\section{KESIMPULAN}

dari musik tradisi melayu menjadi musik tradisi melayu yang memilik citarasa musik jazz. Sehingga bisa menumbuh kembangkan keinginan masyarakat "yang bukan penikmat seni" menjadi tertarik untuk melihat dan mendengar musik tradisi melayu jazz karena itu adalah suatu karya untuk pengembangan 
kebudayaan dari bidang kesenian musik yang ada di Kota Pekanbaru Riau.

\section{DAFTAR PUSTAKA}

Bakar, Abdul Latif Abu. (2000), Media Dan Warisan Seni Rumpun Melayu dalam Nusantara, Kuala lumpur: Jabatan Pengkajian Media Universiti Malaya.

Daud, Hamzah. (1974), "Perkembangan Musik Pop Hingga Sekarang". Kertas kerja Seminar Muzik Nasional, 3 November 1974.

Sugiyono, (2010), Memahami Penelitian Kualitatif. Bandung: CV. Alfabeta

Sumaryono, (2003), Restorasi dan Tranformasi Budaya, Yogyakarta: Lembaga Kajian Pendidikan dan Humaniora Indonesia.

Soedarsono, (1998), Seni Pertunjukan Indonesia di Era Globalisasi. Jakarta: Direktorat Jendral Pendidikan Tinggi Departemen Pendidikan dan Kebudayaan.

Maleong J, Lexy. (1998), Metode Penelitian, Yogyakarta : Rineka Cipta. 